\title{
Kollaboratiivisen vuorovaikutuksen karikoita pk-yritysten kansainvälistymisessä
}

\author{
Pipsa Purhonen
}

\section{Tiivistelmä}

Kansainvälistyminen, yksittäisten toimijoiden riittämättömät resurssit ja organisaatioiden keskinäinen riippuvuus ovat lisänneet yhteistyön tarvetta yhteiskuntamme kaikilla sektoreilla. Artikkelissani ${ }^{1}$ tarkastelen suomalaisten pk-yritysten kansainvälistymistä, joka edellyttää kollaboratiivista vuorovaikutusta. Pohdin kollaboratiivisen vuorovaikutuksen haasteita ja ongelmia sekä niiden hallintaa erityisesti pk-yritysten ja kansainvälistymisessä keskeisten välittäjäorganisaatioiden, kuten kauppayhdistysten ja teknologia- sekä innovaatiokeskusten, edustajien yhteistyösuhteissa. Tavoitteenani on selvittää, millaisia näkemyksiä ja kokemuksia pk-yritysten ja välittäjäorganisaatioiden edustajilla on kollaboratiivisen vuorovaikutuksen karikoista suomalaisten pk-yritysten kansainvälistymisessä Kiinaan.

Tutkimusaineistoni $(\mathrm{N}=91)$ on laadullista, ja se on kerätty verkkokyselyllä Suomesta ja Kiinasta vuonna 2009. Sisällönanalyysi pk-yritysten $(n=34)$ ja välittäjäorganisaatioiden edustajien $(n=57)$ vastauksista avoimiin kysymyksiin osoittaa, että kollaboratiivisen vuorovaikutuksen karikot pk-yritysten kansainvälistymisessä liittyvät 1) relationaalisen viestinnän ja tehtäväviestinnän riittämättömyyteen tai epätasapainoon, 2) viestintäeettisiin ongelmiin ja 3) yhteistyön toimintaympäristöstä nouseviin vuorovaikutushaasteisiin. Avaan ja analysoin näitä tutkimuksen keskeisiä tuloksia erityisesti dialogisen viestintäetiikan ja vuorovaikutusosaamisen näkökulmista. Tutkimustulokset lisäävät niin teoreettista kuin käytännönkin ymmärrystä yhteistyöstä interpersonaalisena viestintänä.

Asiasanat: dialoginen viestintäetiikka, kollaboratiivinen vuorovaikutus, organisaatio, pk-yritys, vuorovaikutusosaaminen, yhteistyösuhde 


\section{Johdanto}

Talouden globalisaatio on lisännyt paitsi yritysten kansainvälistymistä, myös elinkeinoelämän toimijoiden tarvetta yhteistyöhön ja verkostoitumiseen (ks. Koskenlinna ym. 2005, 14-15). Globalisaatiossa on yhä enemmän kyse kansainvälisten, toisistaan riippuvaisten yksilöiden vuorovaikutuksesta kuten tiimityöstä tai vuorovaikutussuhteiden ja -allianssien luomisesta, ylläpitämisestä ja kehittämisestä (ks. myös Charles 2009). Tässä artikkelissa tarkastelen pienten ja keskisuurten yritysten kansainvälistymistä, joka toteutuu usein pk-yritysten ja välittäjäorganisaatioiden, kuten alueellisten kehittämisyhtiöiden, teknologia- ja innovaatiokeskusten tai julkishallinnon organisaatioiden, edustajien yhteistyössä. Lähestyn pk-yritysten ja välittäjäorganisaatioiden edustajien kollaboratiivista vuorovaikutusta eli yhteistyötä interpersonaalisen viestinnän näkökulmasta, kahdenvälisenä sosiaalisena vuorovaikutuksena.

Tarkastelen kollaboratiivista vuorovaikutusta erityisesti suomalaisten pk-yritysten kansainvälistymisessä Kiinaan. Kiinassa toimivia suomalaisyrityksiä on jo yli 200, mutta vähäiset resurssit ja kumppaniverkostot haastavat edelleen pk-yritysten kansainvälistymistä (Mikkola \& Pirttimäki 2007, 7, 24-25). Pk-yritykset tarvitsevat niin virallisia kuin epävirallisiakin yhteistyösuhteita, joiden avulla ne voivat saavuttaa puuttuvia resursseja ja uusia liiketoimintaverkostoja ja -alliansseja (ks. Forsman, Hinttu \& Kock 2002; Ojala 2008). Henkilökohtaisten vuorovaikutussuhteiden merkitys korostuu eritoten kiinalaisen liiketoiminnan kontekstissa ja pk-yritysten kansainvälistymisen alkuvaiheessa, sillä henkilökohtaiset suhteet voivat vähentää liiketoimintaan sisältyviä riskejä kuten opportunismia (ks. Ai 2006, So \& Walker 2006, 16-17). Suomalaisten pk-yritysten kansainvälistyminen Kiinaan edellyttääkin sekä kansallisia että kansainvälisiä, organisaatioiden ja toimialojen rajat ylittäviä yhteistyösuhteita.

Artikkelin tarkoituksena on hahmottaa kollaboratiivista vuorovaikutusta kansainvälistymisessä keskeisissä yhteistyösuhteissa sellaisena, kuin pk-yritysten ja välittäjäorganisaatioiden edustajat sen näkevät ja kokevat. Vaikka pk-yritysten kansainvälistymisen tutkimus on korostanut yhteistyökumppaneiden ja sosiaalisten verkostojen merkitystä kansainvälistymisprosessissa (ks. esim. Agndal \& Chetty 2007; Ellis 2007; Kontinen 2011; Ojala 2008), se ei ole syventynyt pohtimaan yhteistyösuhteiden edellyttämää kollaboratiivista vuorovaikutusta. Toisaalta kollaboratiivisen vuorovaikutuksen monitieteinen tutkimus on keskittynyt tarkastelemaan yhteistyötä pääosin organisaatioiden tasolla, kuten organisatorisina rakenteina ja prosesseina, muttei ole juuri huomioinut interpersonaalisen viestinnän merkitystä (ks. Keyton, Ford \& Smith 2008; Koschmann 2010). Organisaatioiden välinen yhteistyö on kuitenkin havaittavissa juuri yksilöiden, ei organisaatioiden vuorovaikutuksena (Keyton, Ford \& Smith 2008, 385). Yhteistyötä luodaan, ylläpidetään ja kehitetään sosiaalisessa vuorovaikutuksessa. 
Kollaboratiivista vuorovaikutusta (collaborative interaction) on tarkasteltu usealla tieteenalalla. Siitä huolimatta käsitteelle ei ole vakiintunutta merkitystä tai määritelmää (esim. Stohl \& Walker 2002, 240; Lewis 2006). Kasvatustieteissä kollaboratiivisuudesta on keskusteltu oppimisen yhteydessä, jolloin kollaboraatio on nähty jaettujen merkitysten ja yhteisen ymmärryksen rakentamisena vuorovaikutuksessa toisten ihmisten kanssa (Häkkinen \& Arvaja 1999, 209). Kollaboratiivisen oppimisen (collaborative learning) suomenkielisenä vastineena on käytetty myös yhteistoiminnallisen oppimisen käsitettä, mutta Häkkinen ja Arvaja $(1999,209)$ näkevät sen usein virheellisesti yhdistettävän pelkästään työnjaollisiin opetusmenetelmiin (co-operative learning). Samasta syystä käytän esimerkiksi yhteistoiminnallisen vuorovaikutuksen tai yhteistyöviestinnän sijaan käsitettä kollaboratiivinen vuorovaikutus. Tällä käsitevalinnalla korostan paitsi merkitysten jakamista ja niistä neuvottelua, myös yhteistyökumppaneiden yhteistä vastuuta ja panosta tavoitteiden saavuttamiseksi.

\section{Kollaboratiivinen vuorovaikutus organisaatioiden välisessä yhteistyössä}

Interpersonaalista viestintää on ollut tapana hahmottaa dynaamisena, muuttuvana ja epävirallisena kahdenvälisenä vuorovaikutuksena, joka voi toteutua kasvokkain tai teknologiavälitteisesti (Knapp ym. 2002, 8-9). Viestinnän tutkimuskirjallisuudessa kollaboratiivista vuorovaikutusta on määritelty samaan tapaan luonteeltaan vapaaehtoiseksi ja aktiiviseksi toiminnaksi, joka ajan myötä muuttuu ja kehittyy (ks. Lewis 2006, 213-220). Keskeistä määritelmissä on myös vuorovaikutussuhde. Kollaboratiivisen vuorovaikutuksen on katsottu vaarantuvan, mikäli yhteistyökumppanit eivät jaa samoja tavoitteita, ole riippuvaisia toisistaan, osallistu yhtäläisellä panoksella yhteistyöhön tai tee päätöksiä yhdessä (Keyton \& Stallworth 2003, 240).

Pk-yritysten ja välittäjäorganisaatioiden kollaboratiivisessa vuorovaikutuksessa on kyse yhteistyöstä työn kontekstissa, yli organisaatioiden rajojen. Organisaatioiden välisen kollaboraation kriteerinä ja erona työnjakoon perustuvaan yhteistyöhön on pidetty sitä, että yhteistyö koskee tasapuolisesti kaikkia asianosaisia ja tuottaa yhteistyökumppaneiden eroja hyödyntämällä ratkaisuja, jotka ovat paitsi synergisiä myös innovatiivisia (Hardy, Lawrence ja Grant 2005, 58). Kollaboratiivista vuorovaikutusta organisaatioiden välisessä kontekstissa luonnehtivat kuitenkin usein monenlaiset jännitteet, jotka juontuvat yksilöiden, yhteistyöryhmien ja taustaorganisaatioiden eriävistä tavoitteista (Heath \& Frey 2004, 196). Lisäksi yhteistyön hyödyt konkretisoituvat harvoin tasavertaisesti kaikille yhteistyökumppaneille tai heidän edustamilleen organisaatioille.

Pk-yritysten ja välittäjäorganisaatioiden edustajien kollaboratiivisessa vuorovaikutuksessa voi ilmetä erityisesti organisaatioiden väliselle yhteistyölle ominaisia jännitteitä kuten yksilön ja organisaation tai julkisen ja yksityisen välinen 
jännite (Keyton, Ford \& Smith 2008). Yksilön ja organisaation välinen jännite voi aiheuttaa epävarmuutta siitä, onko yhteistyö yksilöiden vai organisaatioiden välistä, ja ovatko yhteistyökumppanin käsitykset ja mielipiteet hänen omiaan vai edustavatko ne hänen taustaorganisaatiotaan. Mikäli yhteistyökumppanit tulevat elinkeinoelämän eri sektoreilta, on todennäköistä, että heidän tavoitteensa ja toimintatapansa ovat erilaisia (Selsky \& Parker 2005, 851). Yhteistyökumppaneiden eriävät arvot tai ideologiat haastavat todennäköisimmin juuri sektorien rajat ylittävää yhteistyötä (Koschmann 2010). Julkisen ja yksityisen välinen jännite liittyykin esimerkiksi julkisen ja yksityisen sektorin välisiin eroihin ja siihen, kuinka ne vaikuttavat uskomuksiin, olettamuksiin tai informaation jakamiseen (Keyton, Ford \& Smith 2008).

Lisäksi on havaittu, että vapaaehtoisuuden ja strategisuuden sekä henkilökohtaisuuden ja ammatillisuuden väliset jännitteet määrittävät kollaboratiivista vuorovaikutusta pk-yritysten kansainvälistymisen kontekstissa (Purhonen 2010a; 2010b). Pk-yritysten ja välittäjäorganisaatioiden edustajat luovat, ylläpitävät ja kehittävät kollaboratiivista vuorovaikutusta sekä strategisesti että vapaaehtoisesti. Vaikka yhteistyösuhteita luodaan pääasiassa työn kontekstissa, kuten sovituissa tapaamisissa tai messuilla, on osa pk-yritysten ja välittäjäorganisaatioiden edustajista tutustunut pk-yritysten kansainvälistymisen kannalta merkitykselliseen yhteistyötahoon esimerkiksi ystävän tai sukulaisen kautta. Liiketoimintaan kytkeytyvää yhteistyötä voi siis syntyä informaaleissa ja vapaaehtoisesti ylläpidetyissä vuorovaikutusverkostoissa. Toisaalta liiketoimintasuhteista voi kehittyä henkilökohtaisia vuorovaikutussuhteita, jopa ystävyyttä. Yhteistyösuhteista voidaankin puhua sulautettuina vuorovaikutussuhteina (blended relationships, Bridge \& Baxter 1992), jotka toteuttavat sekä henkilökohtaisia että työrooliin liittyviä tehtäviä. Pk-yritysten ja välittäjäorganisaatioiden kollaboratiiviseen vuorovaikutukseen voi kuitenkin liittyä myös etäännyttämistä (depersonalization, Sias \& Perry 2004), sillä osa yhteistyökumppaneista intentionaalisesti välttää henkilökohtaisia puheenaiheita eikä ole motivoitunut ylläpitämään vuorovaikutussuhdetta sen jälkeen, kun yhteistyössä on saavutettu sille asetetut tehtävätavoitteet (Purhonen 2010b, 15).

Kollaboratiivisella vuorovaikutuksella on pk-yritysten kansainvälistymisen kontekstissa yhteistyön tuloksellisuuteen liittyviä tehtäviä, kuten tiedon jakaminen, hallinta ja soveltaminen tai instrumentaalisen tuen tarjoaminen, sekä relationaaliseen viestintään eli vuorovaikutussuhteen luomiseen, ylläpitämiseen ja kehittämiseen kytkeytyviä tehtäviä (Purhonen 2010b). Organisaatioiden välisen yhteistyön kontekstissa kollaboratiivisen vuorovaikutuksen voidaan katsoa edellyttävän myös jännitteisyyden ja moninaisuuden hallintaa.

Vaikka kollaboratiivista vuorovaikutusta tarkasteltaisiinkin interpersonaalisen viestinnän näkökulmasta, on kollaboratiivisen vuorovaikutuksen luonteen ymmärtämiseksi huomioitava myös yhteistyön laajempaa kontekstia ja toimintaympäristöä. Vuorovaikutussuhteen osapuolet ovat erilaisten ryhmien, verkos- 
tojen ja yhteisöjen jäseniä, mikä vaikuttaa esimerkiksi kahdenvälisen vuorovaikutuksen normeihin ja rakenteisiin (Knapp ym. 2002, 8).

Pk-yritysten ja välittäjäorganisaatioiden edustajien kollaboratiivista vuorovaikutusta, kuten työpaikan viestintää ja vuorovaikutussuhteita yleensä, voidaan tarkastella ekologisena systeeminä. Sias, Krone ja Jablin (2002) hahmottavat työpaikan vuorovaikutussuhteiden kehittyvän neljällä, toisiinsa vaikuttavalla ekosysteemin tasolla: 1. mikrosysteemin tasolla, joka käsittää yksilöiden keskinäiset vuorovaikutussuhteet, 2. mesosysteemin tasolla, joka kuvaa vuorovaikutussuhteiden riippuvuutta toisistaan, 3. makrosysteemin tasolla, joka vastaa työskentelyorganisaatiota tai sen osia, sekä 4. eksosysteemin tasolla, jolle voidaan sijoittaa laajempia merkityssysteemejä kuten kulttuuriset tai poliittiset ideologiat. Pk-yritysten ja välittäjäorganisaatioiden edustajien kollaboratiivinen vuorovaikutus on tällöin mikrosysteemi, johon vaikuttavat esimerkiksi yhteistyökumppaneiden tiimit, ryhmät ja verkostot (mesosysteemi), taustaorganisaatioiden ja -yritysten erilaiset toimintatavat tai odotukset (makrosysteemi) sekä heidän edustamiensa toimialojen, sektoreiden tai kansallisten kulttuurien erityispiirteet (eksosysteemi).

Kollaboratiivinen vuorovaikutus on siis riippuvaista ekosysteemin eri tasoista. Esimerkiksi yhteistyön kannalta merkityksellisen tiedon hankkiminen tai sen soveltaminen voi riippua yhteistyökumppaneiden verkostoista (Stohl \& Walker 2002, 245). Toisaalta mikrotaso, eli pk-yritysten ja välittäjäorganisaatioiden edustajien yhteistyö, vaikuttaa toisiin ekosysteemin tasoihin. Kollaboratiivinen vuorovaikutus interpersonaalisen viestinnän tasolla voi edistää esimerkiksi organisaatioiden tavoitteiden saavuttamista tai laajempaa kehitystä, kuten alueellista hyvinvointia.

Yhteistyön haastavasta ja jännitteisestä luonteesta johtuen pyrin tässä artikkelissa ymmärtämään erityisesti kollaboratiivisen vuorovaikutuksen "pimeää puolta". Erityisen tärkeää on mielestäni tarkastella organisaatioiden välisen yhteistyön esteitä ja ongelmia interpersonaalisen viestinnän näkökulmasta ja pyrkiä ymmärtämään sitä, millaisen haasteen ne luovat yhteistyökumppaneille ja heidän vuorovaikutusosaamiselleen.

\section{Tutkimuksen toteuttaminen}

\section{Tutkimustehtävä ja -kysymykset}

Tutkimuksen tarkoituksena on pohtia kollaboratiivisen vuorovaikutuksen haasteita ja ongelmia sekä niiden hallintaa pk-yritysten ja kansainvälistymisessä keskeisten välittäjäorganisaatioiden, kuten kauppayhdistysten ja teknologia- sekä innovaatiokeskusten, edustajien yhteistyösuhteissa. Tutkimuksen kontekstina on suomalaisten pk-yritysten kansainvälistyminen Kiinaan. Pyrin ymmärtämään kollaboratiivisen vuorovaikutuksen karikoita sellaisina, kuin yhteistyö- 
hön osallistuvat yksilöt eli pk-yritysten ja välittäjäorganisaatioiden edustajat ne ymmärtävät ja kokevat. Tutkimustani ohjaakin tutkimuskysymys:

1. Millaisia näkemyksiä ja kokemuksia pk-yritysten ja välittäjäorganisaatioiden edustajilla on kollaboratiivisen vuorovaikutuksen esteistä ja ongelmista suomalaisten pk-yritysten kansainvälistymisessä Kiinaan?

\section{Tutkimusaineisto ja analyysi}

Tutkimusaineistoni $(\mathrm{N}=91)$ on laadullista ja se on kerätty verkkokyselyllä Suomesta ja Kiinasta vuonna 2009. Pyyntö osallistua tutkimukseen julkaistiin kolmella verkkosivustolla, jotka käsittelivät suomalaisten pk-yritysten kansainvälistymistä Kiinaan. Lisäksi otin pk-yritysten ja välittäjäorganisaatioiden edustajiin yhteyttä sähköpostitse erilaisten sähköpostilistojen ja jäsenluetteloiden perusteella.

Aineisto sisältää pk-yritysten ( $\mathrm{n}=34)$ ja välittäjäorganisaatioiden edustajien $(n=57)$ vastauksia avoimiin kysymyksiin, joissa pyydettiin kuvailemaan epäonnistunutta yhteistyösuhdetta (Millainen on mielestäsi epäonnistunut yhteistyösuhde? Voit pohtia esimerkiksi sitä, mikä erottaa epäonnistuneen yhteistyön onnistuneesta yhteistyöstä? Millaiset seikat voivat johtaa yhteistyösuhteen epäonnistumiseen?). Enemmistö vastaajista oli suomalaisia $(\mathrm{n}=81)$, mutta osallistujia oli myös Kiinasta $(n=5)$, Ruotsista $(n=3)$, Norjasta $(n=1)$ ja Taiwanista $(\mathrm{n}=1)$. Tutkimukseen osallistuneista pk-yritysten ja välittäjäorganisaatioiden edustajista 71 oli miehiä ja 19 naisia (1 raportoimaton). Osallistujien ikä vaihteli 26 ikävuodesta 71 vuoteen $(\mathrm{ka}=48)$.

Pk-yritysten ja välittäjäorganisaatioiden edustajien kirjoittamat kuvaukset epäonnistuneesta yhteistyöstä vaihtelivat tiiviistä muutaman adjektiivin listoista yksityiskohtaisiin usean virkkeen määritelmiin ja tarinoihin. Yhteensä kirjoitettua aineistoa oli noin 35 liuskaa. Aineistolähtöiselle sisällönanalyysille (Neuendorf 2002) ominaisesti pyrin aluksi hahmottamaan kokonaiskuvan aineistosta, mikä olikin melko ongelmatonta. Vastaajat kuvasivat kollaboratiivisen vuorovaikutuksen karikoita toisaalta yhteistyökumppaneiden vuorovaikutuksen, toisaalta yhteistyösuhteen ulkopuolisten, kontekstuaalisten tekijöiden tasolla. Jatkoin analyysia näiden aihekokonaisuuksien pohjalta tarkastelemalla aineistoa yksityiskohtaisemmin. Koodasin pk-yritysten ja välittäjäorganisaatioiden edustajien vastauksia niiden merkityssisällön perusteella ja etsien sisällöllisiä yhdenmukaisuuksia ja eroja. Tämä auttoi minua jäsentämään ja erottelemaan aineistoa edelleen ja muodostamaan lopulliset analyysiluokat.

\section{Tulokset}

Tutkimuksen tavoitteena oli tarkastella pk-yritysten ja välittäjäorganisaatioiden edustajien näkemyksiä ja kokemuksia kollaboratiivisen vuorovaikutuksen 
esteistä ja ongelmistä suomalaisten pk-yritysten kansainvälistymisessä Kiinaan. Aineistolähtöisen sisällönanalyysin perusteella kollaboratiivisen vuorovaikutuksen karikkoja ovat 1) tehtäväviestinnän ja relationaalisen viestinnän riittämättömyys tai epätasapaino, 2) viestintäeettiset ongelmat ja 3) yhteistyön toimintaympäristöstä nousevat vuorovaikutushaasteet. Kuvaan näitä tutkimustuloksia seuraavaksi tarkemmin ja käyttämällä aineistoesimerkkejä. Autenttisuuden varmistamiseksi en ole kääntänyt aineistonäytteitä, vaan ne ovat suomeksi ja englanniksi. Numerot aineistoesimerkkien perässä viittaavat vastaajan tunnisteeseen.

\section{Tehtäväviestinnän ja relationaalisen viestinnän riittämättömyys tai epätasapaino}

Pk-yritysten ja välittäjäorganisaatioiden edustajien kuvaukset kollaboratiivisen vuorovaikutuksen karikoista kertovat viestinnän riittämättömyydestä. Äärimmillään "kommunikaation" katsottiin puuttuvan täysin. Yleensä vastauksissa kuvattiin joko riittämätöntä panostusta yhteistyön tuloksellisuutta edistävään vuorovaikutukseen, josta käytän tässä käsitettä tehtäväviestintä, tai suhdetason vuorovaikutuksen eli relationaalisen viestinnän laiminlyöntiä. Tehtäväviestinnän tai relationaalisen viestinnän riittämättömyyden lisäksi niiden epätasapaino nähtiin kollaboratiivisen vuorovaikutuksen karikkona. Pk-yritysten ja välittäjäorganisaatioiden edustajat kirjoittivat epäonnistuneista yhteistyösuhteista, joissa tehtäväviestintään keskitytään relationaalisen viestinnän kustannuksella tai vastaavasti yhteistyösuhteen ylläpitämisestä ja kehittymisestä huolehditaan siinä määrin, ettei yhteistyön tulostavoitteita saavuteta.

Pk-yritysten ja välittäjäorganisaatioiden edustajat pitivät ongelmallisena sellaista kollaboratiivista vuorovaikutusta, jossa yhteistyön tehtävistä ja tavoitteista ei keskustella riittävästi, vaan ne jäävät epäselviksi ja konkretisoimattomiksi ja yhteistyökumppaneilla on niistä eriäviä käsityksiä. Kirjoitettujen kuvausten perusteella tehtäväviestintä on puutteelllista, mikäli yhteistyökumppanit eivät jaa yhteistyön tavoitteita edistävää tietoa tai yhteistyöhön liittyvistä seikoista tiedottaminen on hidasta tai "epäkorrektia". Riittämätön tehtäväviestintä on pk-yritysten ja välittäjäorganisaatioiden edustajien mukaan tuloksetonta, tehotonta ja paikallaan pysyvää. Tähän voivat vastaajien mielestä johtaa esimerkiksi sitoutumisen puute, heikko tai "hutiloitu" työpanos, kyvyttömyys tai haluttomuus päätöksentekoon sekä kärsimättömyys, jolloin "odotetaan liian nopeita tuloksia". Oheiset aineistoesimerkit kuvaavat yhteistyötä, jossa ei riittävästi jaeta tietoa tai neuvotella yhteistyön tavoitteista, työskentelytavoista tai resursseista.

"Jos ei riittävästi keskustella tavoitteista ja niiden saavuttamiseksi vaadittavista keinoista ja panostuksista ennen sopimuksen tekoa ja yhteistyön aloittamista, tulee varmasti ongelmia, syytöksiä ja virheitä, joista vastuuta vieritetään aina toisille. Yhteisymmärrys ja tilanteesta 
tehty yhteinen analyysi johtopäätöksineen on välttämätöntä ennen prosessin käynnistämistä." (67)

"Epäonnistunut suhde johtaa oleellisen tiedon tai yhteyksien panttaamiseen ja siihen, että se pieni työntöapu, jolla kuorma saadaan liikkeelle ei ole aina saatavissa. Epäonnistunut suhde johtaa siihen, että suoritteita yritysten välillä ei ole riittävän hyvin määritelty ennen aloitusta, mutta niitä perataan täikammalla jälkikäteen.” (44)

Pk-yritysten ja välittäjäorganisaatioiden edustajien mukaan kollaboratiivisessa vuorovaikutuksessa tulisi huomioida yhteistyökumppania ja vuorovaikutussuhdetta. Pk-yritysten ja välittäjäorganisaatioiden edustajien mielestä yhteistyösuhde epäonnistuu, mikäli "se perustuu yksinomaan laskutukseen", eikä suhteessa "panosteta riittävästi suhteen ja luottamuksen rakentamiseen". Kirjoitettujen kuvausten perusteella yksipuolisuus tai epäaktiivuus eivät riitä yhteistyösuhteen ylläpitämiseen, vaan suhteen tulee olla vastavuoroinen. Muutoin voi syntyä "sanelupolitiikkaa" tai "haluttomuus aitoon vuorovaikutukseen torpedoi suhteen".

Vastaajien mielestä kollaboratiivisen vuorovaikutuksen ongelmaksi tai esteeksi voi tulla tehtäväviestinnän ja relationaalisen viestinnän epätasapaino. Aineiston perusteella kollaboratiivisessa vuorovaikutuksessa saatetaan pyrkiä yhteistyön tuloksellisuuteen siinä määrin, että vuorovaikutussuhde kärsii. Pk-yritysten ja välittäjäorganisaatioiden edustajien käsitysten mukaan yhteistyösuhdetta ei kuitenkaan voida ylläpitää pelkästään henkilökohtaisella tai epävirallisella tasolla. Vastaajien määritelmien perusteella ei olekaan yksiselitteistä, missä määrin yhteistyösuhteessa tulisi korostaa tuloksellisuutta tai yhteistyön liiketaloudellisia hyötyjä ja missä määrin vuorovaikutussuhteen ylläpitämistä ja kehittämistä. Aineistossa tulee esille hyvin vastakkaisiakin näkemyksiä ja odotuksia tehtäväviestinnästä ja relationaalisesta viestinnästä osana kollaboratiivista vuorovaikutusta, kuten seuraavat esimerkit osoittavat.

"Kilpailu on niin kovaa, että mihinkään ylimääräiseen kimppakivaan tai seurusteluun ei enää ole valitettavasti kenelläkään aikaa. joka asialle lyödään ainakin laskennallinen hintalappu. Lisäksi uudet kontaktit haetaan suoraan Googlettamalla, tai esim. messuilta. Epäonnistunut (verkosto) on se joka ei tuo kassavirtaa, siis ordereita. [.....] Eli lyhyesti, painopiste yhteistyösuhteissa on yhä enempi, korostuneempi kovan osaamisen know how puolella, kuin "pehmeissä" sosiaalisissa suhteissa." (32)

"Epäonnistunut yhteistyösuhde on yksipuolinen, "voitonhakuinen" ja suhde, jossa toinen osapuoli ei aidosti ole kiinnostunut toisen osapuo- 
len asioista eikä kunnioita henkilönä. Nyky aikana raadollinen voitonhakuinen työskentelyilmapiiri saattaa ajaa tähän.” (19)

"I would say that social and emotional connectedness is the most important single issue for commercially successful business. If you are not socially accepted by a group, it does not matter how well you do your work, you will be disqualified anyway. This is why I seek social connectedness in my clients." (89)

\section{Viestintäeettiset ongelmat}

Pk-yrittäjien ja välittäjorganisaatioiden edustajien kuvaukset kollaboratiivisen vuorovaikutuksen varjopuolista sisälsivät luonnehdintoja erilaisista viestintäeettisistä ongelmista. Tällaiset luonnehdinnat koskivat esimerkiksi epäluottamusta, salailua tai avoimuuden puutetta sekä suoranaista epärehellisyyttä. Vastausten perusteella yhteistyötä voivat varjostaa itsekkyys ja oman edun tavoittelu. Aineisto sisälsi myös kuvauksia epäonnistuneesta kollaboratiivisesta vuorovaikutuksessa, jossa yhteistyökumppanit eivät kunnioita toisiaan tai toistensa työpanosta tai eivät näe toisiaan tasavertaisina.

Pk-yritysten ja välittäjäorganisaatioiden edustajien mukaan epäluottamus on yksi keskeisimmistä viestintäeettisistä ongelmista kansainvälisen liiketoimintayhteistyön kontekstissa, jossa yhteistyökumppanit voivat olla myös toistensa kilpailijoita. On mahdollista, että "luottamussuhdetta ei synny tai luottamus petetään". Kilpailuasetelman lisäksi epäluottamus voi vastaajien mukaan juontua "ristiriidasta tavoitteissa" tai "lupausten rikkomisesta". Yhteistyökumppaneilla voi olla "piiloagendoja" ja esimerkiksi yhteistyötä "muiden asiaan vaikuttavien tahojen kanssa" saatetaan salailla. Alla olevat aineistoesimerkit havainnollistavat erityisesti avoimuuden puutetta kollaboratiivisen vuorovaikutuksen karikkona.

"Epäluottamus (asioita ei kerrota suoraan, vaan ne selviävät muuta kautta). Kumppani ei vastaavasti kerro mitään vapaaehtoisesti jos luottamusta ei löydy. "(76)

"Ei kerro ajoissa totuutta, joka voi aiheuttaa taloudellisia tai muita menetyksiä. Normaalisti vaietaan jos ei ole uutta kerrottavaa tai jos asiat ovat huonosti. Jos ei kerrota, että asiat eivät järjesty ja toiselle aiheutuu kustannuksia, se horjuttaa yhteistyösuhdetta." (74)

Epäluottamuksen ja avoimuuden puutteen lisäksi pk-yritysten ja välittäjäorganisaatioiden edustajat mainitsivat epärehellisyyden kollaboratiivisen vuorovaikutuksen esteenä. Yhteistyökumppanit voivat antaa virheellistä tietoa erityisesti omasta osaamisestaan ja resursseistaan. Niin epärehellisyys kuin avoimuuden puutekin voivat pk-yritysten ja välittäjäorganisaatioiden edustajien mielestä joh- 
tua siitä, että yhteisten tavoitteiden sijaan toinen tai molemmat yhteistyökumppaneista pyrkivätkin edistämään vain omaa etuaan. Osa vastaajista näkeekin mahdottomana sellaisen yhteistyösuhteen, jossa toinen osapuoli pyrkii "maksimoimaan omat hyötynsä" tai jossa "ollaan valmiita yhteistyöhön vain kun se hyödyttää itseään". Yksipuolisen hyödyn tavoittelu voi johtaa ikäviin lopputulemiin, joita vastaajat listaavat alla olevissa esimerkeissä.

"Toisen hyväksikäyttö millä vain tavalla. Ottaminen antamatta. Yhteisen hyvän tai tiedon väärinkäyttö.” (15)

"Jos toinen osapuoli vaan pumppaa tietoa ja tinkii hintoja, muttei aiokkaan olla yhteistyössä." (83)

\section{Yhteistyön toimintaympäristöstä nousevat vuorovaikutushaasteet}

Kollaboratiivisen vuorovaikutuksen karikoksi voi pk-yritysten ja välittäjäorganisaatioiden edustajien käsitysten mukaan koitua myös erilaiset yhteistyön toimintaympäristöstä nousevat viestintähaasteet. Nämä haasteet liittyvät esimerkiksi yhteistyökumppaneiden työrooleihin ja -tehtäviin tai taustaorganisaatioiden kulttuureihin ja toimintatapoihin. Kollaboratiivista vuorovaikutusta haastavat pk-yritysten ja välittäjäorganisaatioiden edustajien mielestä myös kulttuuriset erot sekä pk-yritysten puutteelliset resurssit ja yritysten muutoinkin haastava asema kansainvälisen liiketoiminnan kontekstissa.

Pk-yritysten ja välittäjäorganisaatioiden edustajien kirjoittamien kuvausten perusteella kollaboratiivista vuorovaikutusta monimutkaistavat erilaiset yhteistyökumppaneiden ja heidän taustaorganisaatioidensa väliset vuorovaikutusongelmat. On esimerkiksi mahdollista, ettei yhteistyökumppaneita ole "asianmukaisesti informoitu oman yrityksen johdon taholta" tai johto päinvastoin puuttuu tarpeettomasti yhteistyöhön ja häiritsee sen rutiineja. Taustaorganisaatio voi "alkaa kilpailemaan projektin suorittamisessa". Lisäksi yhteistyökumppaneiden henkilökohtaiset asenteet ja tehtäväroolin odotukset voivat olla ristiriidassa. Esimerkki tällaisesta tilanteesta on erään välittäjäorganisaation edustajan kuvaus yhteistyökumppanista, joka on haluton yhteistyöhön, vaikka se kuuluisi hänen työtehtäviinsä.

Yhteistyökumppaneiden taustaorganisaatioiden viestintäkulttuurit ja toimintatavat eroavat vastaajien mielestä joskus perustavanlaatuisellakin tavalla. Osa pk-yritysten edustajista piti virkamiesten ja julkishallinnon edustajien vuorovaikutusta tuloksettomana. Toisaalta yhteistyökumppanit eroavat työhistorialtaan tai vaikkapa teknologiselta osaamiseltaan. Tämä voi aiheuttaa viestintäongelmia ja -haasteita kollaboratiivisessa vuorovaikutuksessa, kuten seuraavat esimerkit konkretisoivat. 
"Hyvin suuri kuilu on se kokemuksen, tiedon ja erityisesti kansainvälisen vuorovaikutuksen ymmärtämisen kuilu asiantuntijan ja asiakkaan välillä. Millä välittää yli 30 v:n kokemus henkilölle, joka on tämän taipaleen ensiaskeleilla." (66)

"Asiakas voi vaatia teknisiä mahdottomuuksia joiden juuret eivät ole tarpeeseen sidottuja vaan tulevat jostain "varmuuden vuoksi" ja juontavat tekniseen tietämättömyyteen." (65)

Pk-yritysten ja välittäjäorganisaatioiden edustajien käsitysten suomalaisen ja kiinalaisen liiketoimintakulttuurin eroavaisuudet tuovat viestintähaasteita suomalaisten yritysten kansainvälistymisessä Kiinaan. Vastaajien mielestä suomalaisilla ja kiinalaisilla yhteistyökumppaneilla on eriäviä käsityksiä esimerkiksi päätösten ja sopimusten sitovuudesta. Pk-yritysten ja välittäjäorganisaatioiden edustajat kuvasivat kollaboratiivisen vuorovaikutuksen kiinalaisten yhteistyökumppaneiden kanssa vaativan tiheää yhteydenpitoa sekä sitoutumista quanxi:n, palveluksia ja vastapalveluksia edellyttävien henkilökohtaisten vuorovaikutussuhteiden ja -verkostojen, pitkäjänteiseen rakentamiseen ja ylläpitämiseen. Vastaajien mielestä nämä kiinalaisen liiketoimintakulttuurin erityispiirteet luovat vaatimuksia suomalaisten yhteistyökumppaneiden vuorovaikutuskäyttäytymiselle, mitä seuraavat lainaukset kuvastavat.

"Suhteiden ylläpito edellyttää molemminpuolista toimintaa, ainakin toisen osapuolen tulee vastata, vaikkei voisi asiaa silloin hoitaa. Suomalaiset eivät vastaile nopeasti kyselyihin. Kiinalaiset odottavat vastausta "viimeistään huomenna" ja viesti tulee eri tavoin, jos vastausta ei tule s.postilla ..(seuraavaksi faksilla ja soittavat, oletko saanut viestin)." (74)

"Oikeaa kiinalaista Guanxi:ta ei voi ostaa ja sen oppiminen vie vuosia. Suomalaisten yhteistyökumppanien kanssakäyminen on oluen juontia ei oikeaa businesta." (23)

Vastaajien käsitysten mukaan haasteita yhteistyöhön voivat lisäksi aiheuttaa pkyritysten vaikea asema kilpaillussa ja dynaamisessa liiketoimintakontekstissa sekä resurssien, kuten rahoituksen, markkinoinnin tai osaamisen, puute. Nämä tekijät voivat rajoittaa kollaboratiivisen vuorovaikutuksen mahdollisuuksia ja tuloksellisuutta. Välittäjäorganisaation edustajan kommentti kiteyttää pk-yritysten tilanteen:

"Yleisesti ottaen alani pk-yritykset ovat pieniä. Innovatiivisuutta on, mutta kauppaa vähän. Ilman rahaa ei ole mahdollista onnistua." (71) 


\section{Pohdintaa}

\section{Kollaboratiivisen vuorovaikutuksen karikot ja dialoginen viestintäetiikka}

Tämän tutkimuksen tavoitteena oli pohtia kollaboratiivisen vuorovaikutuksen esteitä ja ongelmia suomalaisten pk-yritysten kansainvälistymisessä Kiinaan. Tutkimustulosten perusteella pk-yritysten ja välittäjäorganisaatioiden edustajien kollaboratiivista vuorovaikutusta voivat varjostaa tehtäväviestinnän ja relationaalisen viestinnän riittämättömyys tai epätasapaino, viestintäeettiset ongelmat sekä yhteistyön toimintaympäristöstä nousevat vuorovaikutushaasteet. Nämä tulokset tukevat ekologisen systeemin näkökulman (Sias, Krone \& Jablin 2002) soveltamista kollaboratiivisen vuorovaikutuksen tarkasteluun. Tehtäväviestinnän ja relationaalisen viestinnän määrään ja laatuun sekä viestinnän eettisiin periaatteisiin liittyy erilaisia henkilö-, organisaatio-, toimiala- ja kulttuurikohtaisia odotuksia, arvostuksia ja tottumuksia. Kollaboratiivisen vuorovaikutuksen karikoihin vaikuttavat siis mikrosysteemin (kuten yhteistyöhön osallistuvat yksilöt), mesosysteemin (kuten yhteistyöverkostot), makrosysteemin (kuten organisaatio) ja eksosysteemin (kuten kansallinen tai liiketoimintakulttuuri) tasot.

Tulokset kollaboratiivisen vuorovaikutuksen varjopuolista kuvastavat pkyritysten ja välittäjäorganisaatioiden edustajien tapoja jäsentää tätä monin tavoin hajanaista ja epäselvääkin yhteistyökontekstia. Yhteistyökumppaneita kuvataan ja tulkitaan paitsi yksilöinä, myös erilaisten stereotyyppien, kuten "virkamiehet", "suomalaiset" tai "kiinalaiset", valossa. Yleistykset voivat olla haitallisia kollaboratiiviselle vuorovaikutukselle, mutta prototyypeistä eli tyypillisimmistä mielikuvista on havaittu olevan hyötyä yhteistyön alkuvaiheessa. Prototyypit auttavat etsimään eroja ja samankaltaisuuksia kollaboratiiviseen vuorovaikutukseen liittyvistä uskomuksista ja olettamuksista, joiden pohjalta yhteistyökumppaneiden on mahdollista rakentaa yhteistä identiteettiä (Isbell 2010, 20). Juuri jaetun tai kollektiivisen identiteetin saavuttamista on pidetty organisaatioiden välisen yhteistyön tehokkuuden ja innovatiivisuuden mahdollistajana (Hardy, Lawrence \& Grant 2005). Tämän tutkimuksen tulokset, kuten löydökset stereotyyppisistä näkemyksistä tai oman edun tavoittelusta yhteistyössä, saattavat viitata siihen, ettei pk-yritysten ja välittäjäorganisaatioiden edustajien kuvaamissa epäonnistuneissa yhteistyösuhteissa ole saavutettu yhteenkuuluvuutta tai me-henkeä. Tällöin yhteistyöhön osallistujat ovat pikemminkin itsenäisiä toimijoita ja organisaatioidensa edustajia kuin yhtenäinen kollektiivi (ks. Hardy, Lawrence \& Grant 2005, 61-62). Epäonnistuneissa yhteistyösuhteissa on siis voinut olla kyse pelkästään työnjakoon perustuvasta yhteistyöstä (cooperation), ei kollaboraatiosta (collaboration). 
Yhteistyökontekstin diversiteetti ja toisaalta pyrkimus yhteisyyteen tai yhteisymmärrykseen luovat jännitteen kollaboratiiviseen vuorovaikutukseen (ks. myös Zoller 2000). Kollaboratiivisella vuorovaikutuksella on monimuotoinen ja jännitteinen luonne. Se voidaan esimerkiksi nähdä sekä henkilökohtaisena että instrumentaalisena ja samaan aikaan yksilöiden välisenä ja organisaatioita edustavana vuorovaikutuksena. Pk-yritysten ja välittäjäorganisaatioiden edustajien kokemat kollaboratiivisen vuorovaikutuksen karikot kytkeytyvät suurilta osin juuri yhteistyösuhteiden ja yhteistyökontekstin monimuotoisuuteen. Esimerkiksi opportunismi tai yhteistyökumppanin intressien laiminlyönti ovat tyypillisesti koettuja uhkia juuri organisaatioiden välisen yhteistyön kontekstissa (Williams 2007, 597).

Kollaboratiivisen vuorovaikutuksen karikoita on kiinnostavaa pohtia dialogisen viestintäetiikan näkökulmasta, joka korostaa ihmisten erilaisuutta ja vuorovaikutuskontekstien moninaisuutta (esim. Arnett, Harden Fritz \& Bell 2009; Johannesen 2002). Tämän tutkimuksen valossa kollaboratiivisen vuorovaikutuksen tulee pyrkiä luotettavuuteen, rehellisyyteen, avoimuuteen, epäitsekkyyteen sekä yhteistyökumppanin kunnioittamiseen. Nämä eettiset periaatteet ovat dialogisuudelle tunnusomaisia. Dialogisuuteen kuuluu muun muassa toisten huomioonottaminen, supportiivisen ilmapiirin luominen ja aktiivinen läsnäolo vuorovaikutuksessa. Dialoginen viestintäetiikka edellyttää myös sitä, että erilaisuudestaan huolimatta vuorovaikutuskumppanit nähdään keskenään tasavertaisina. (Johannesen 2002, 59-60; ks. myös Valkonen 2003, 139.) Kollaboratiivisen vuorovaikutuksen uhkien ja riskien hallitseminen tai välttäminen vaatii asettautumista toisen asemaan eli toisen näkökulmien, tunteiden ja motiivien ymmärtämistä. Erityisen tärkeää on ymmärtää sitä, millaiset seikat saattavat näyttäytyä yhteistyökumppanille uhkina (Williams 2007, 601). Dialoginen viestintäetiikka kunnioittaa erilaisuutta ja pyrkii oppimaan juuri vuorovaikutuskumppaneiden eroavaisuuksista ja vuorovaikutuskontekstin monimuotoisuudesta (Arnett, Harden Fritz \& Bell 2009). Dialogisuuteen liittyykin näin luovuus. Dialogisuus luo ideoita, ajatuksia ja tuloksia (Heath 2007, 149) eli tukee kollaboratiivisen vuorovaikutuksen instrumentaalisia tavoitteita.

Tutkimustulosten perusteella kollaboratiivinen vuorovaikutus vaatii riittävää tehtävä- ja relationaalista viestintää, panostamatta kumpaankaan toisen kustannuksella. Kollaboratiivisessa vuorovaikutuksessa keskeistä ovat dialogiselle viestintäetiikalle ominaiset periaatteet, kuten luotettavuus, rehellisyys, avoimuus, epäitsekkyys ja toisen kunnioittaminen. Kollaboratiivista vuorovaikutusta ei voi irrottaa toimintaympäristöstään, vaan esimerkiksi yhteistyökumppaneiden taustaorganisaatiot tai liiketoimintakulttuurit säätelevät yhteistyötä. Se, muodostuuko näistä kollaboratiivisen vuorovaikutuksen ominaispiirteistä pk-yritysten kansainvälistymisessä yhteistyön ongelmia tai esteitä, on pitkälti kiinni pk-yritysten ja välittäjäorganisaatioiden edustajista itsestään. Dialogi- 
suuden keskiössä on vuorovaikutukseen osallistujien asennoituminen toisiinsa (Johannesen 2002, 56).

\section{Kollaboratiivisen vuorovaikutuksen karikot ja vuorovaikutusosaaminen}

Organisaatioiden väliseen yhteistyöhön osallistuvia yksilöitä on kutsuttu tutkimuskirjallisuudessa (esim. Isbell 2010; Williams 2002) "rajojenylittäjiksi" (boundary spanners), sillä he työskentelevät yli organisaatioiden sekä tehtävätai toimialakohtaisten rajojen. Heidän on katsottu tarvitsevan työssään erilaisia taitoja, kykyjä sekä ominaisuuksia rakentaakseen ja ylläpitääkseen vuorovaikutussuhteita, hallitakseen yhteistyön monimuotoisuutta tai ymmärtääkseen erilaisia motiiveja, rooleja ja vastuita (Williams 2002, 103). Tätä organisaatioiden tai toimialojen välisessä yhteistyössä tarvittavaa osaamista ei kuitenkaan ole jäsennetty interpersonaalisesta näkökulmasta. Tutkimustuloksia kollaboratiivisen vuorovaikutuksen esteistä ja ongelmista onkin tarpeellista tarkastella pk-yritysten ja välittäjäorganisaatioiden edustajien vuorovaikutusosaamisen haasteena.

Vuorovaikutusosaamisella voidaan hahmottaa olevan kognitiivinen, affektiivinen ja behavioraalinen ulottuvuus (Spitzberg \& Cupach 1984; Spitzberg 2000). Vuorovaikutusosaamiseen liittyy esimerkiksi tietoa viestintäkäyttäytymisestä, metakognitiivisia taitoja ennakoida, suunnitella, säädellä ja arvioida viestintäkäyttäytymistä sekä motivaatiota ja taitoja toimia vuorovaikutuskontekstissa tavalla, jota viestintään osallistuvat pitävät tehokkaana ja tarkoituksenmukaisena (Valkonen 2003, 26). Onkin kiinnostavaa pohtia, miten kollaboratiivista vuorovaikutusta voidaan hallita ja missä määrin sen karikoita voidaan väistää. Millaista tietoa vuorovaikutuskäyttäytymisestä, -strategioista tai -normeista tai millaista motivaatiota olla vuorovaikutuksessa yhteistyön haasteet ja ongelmat edellyttävät? Millaisia vuorovaikutustaitoja pk-yritysten ja välittäjäorganisaatioiden edustajat tarvitsevat ylittääkseen kollaboratiivisen vuorovaikutuksen esteitä?

Kollaboratiivista vuorovaikutusta voidaan hahmottaa tehtäväviestintänä, relationaalisena viestintänä ja dialogisena viestintänä, joka tarkoittaa esimerkiksi jännitteisyyden ja moninaisuuden hallintaa ja eettisten periaatteiden huomioimista vuorovaikutuksessa (ks. Purhonen 2010b). Vuorovaikutusosaamiseen kollaboratiivisessa vuorovaikutuksessa tarvitaan tällöin 1) tietoa tehokkaasta ja tarkoituksenmukaisesta tehtäväviestinnästä, relationaalisesta viestinnästä ja dialogisesta viestinnästä, 2) motivaatiota ja uskallusta ottaa huomioon ja edistää niin yhteistyön tehtävä- kuin suhdetason tavoitteita ja halua noudattaa yhteistyön viestintäeettisiä periaatteita, sekä 3) vuorovaikutustaitoja kuten taito jakaa tietoa, taito tarjota instrumentaalista tukea, taito luoda, ylläpitää ja kehittää yhteistyösuhteita sekä taito hallita erilaisuutta tai yhteistyösuhteen jännitteitä (ks myös Purhonen 2010a; 2010b). 
Tämän tutkimuksen perusteella keskeistä vuorovaikutusosaamisessa on se, että yhteistyökumppanit ymmärtävät kollaboratiivisen vuorovaikutuksen merkityksen ja heillä on tietoa hahmottaa kollaboratiivisen vuorovaikutuksen haastavaa ja jännitteistä luonnetta organisaatioiden välisen yhteistyön kontekstissa. Tämä edellyttää esimerkiksi tietoa kollaboratiivisen vuorovaikutuksen karikoista kuten jännitteisistä tehtäväviestintään ja relationaaliseen viestintään liittyvistä odotuksista, mahdollisista viestintäeettisistä ongelmista yhteistyössä sekä yhteistyön toimintaympäristöstä nousevista viestintähaasteista. Yhteistyökumppaneilla tulee myös olla motivaatiota, halua ja taitoa havaita yhteistyön ongelmia ja esteitä sekä pyrkiä selviytymään niistä.

Vuorovaikutusosaamista pk-yritysten kansainvälistymisessä voidaan tarkastella dialogisesta vuorovaikutussuhteen jännitteiden teorian (Baxter \& Montgomery 1996), näkökulmasta. Tällöin vuorovaikutusosaaminen hahmottuu suhdetason ilmiönä eli yhteistyöhön osallistuvien pk-yritysten ja välittäjäorganisaatioiden edustajien vuorovaikutuksena. Vuorovaikutusosaamisena voidaankin pitää sensitiivisyyttä ja kollaboratiiviseen vuorovaikutukseen kytkeytyvän jännitteisyyden, monimuotoisuuden ja ristiriitaisuuden huomioimista interpersonaalisessa viestinnässä. Vuorovaikutussuhteen jännitteiden teorian näkökulmasta vuorovaikutusosaamiseen tarvitaan tietoa erilaisista vuorovaikutusosaamiseen liittyvistä henkilökohtaisista, relationaalisista ja kulttuurisista normeista ja odotuksista eli esimerkiksi ymmärrystä siitä, millaista viestintää kussakin kontekstissa pidetään tehokkaana ja tarkoituksenmukaisena (ks. Wilson \& Sabee 2003, 8). Vuorovaikutusosaaminen pk-yritysten kansainvälistymisessä edellyttää erilaisuuden ja moniäänisyyden arvostamista sekä halua jatkaa yhteistyösuhteen ylläpitämistä ja kehittämistä. Kollaboratiivisessa vuorovaikutuksessa keskeisiksi vuorovaikutustaidoiksi nousevat tällöin dialogia edistävät taidot kuten kuuntelemisen tai integratiivisen neuvottelun taidot (ks. myös Baxter \& Montgomery 1996, 185-206; Wilson \& Sabee 2003, 8-9, 29-35).

Vuorovaikutussuhteen jännitteitä ja niiden hallintaa osana vuorovaikutusosaamista on korostettu myös muissa työelämäkonteksteissa, kuten johtajan ja johdettavan välisessä vuorovaikutussuhteessa (esim. Rouhiainen-Neunhäuserer 2009). Pk-yritysten kansainvälistymisessä vuorovaikutusosaamista haastavat paitsi vuorovaikutussuhteen jännitteet tai yhteistyösuhteen osapuolten mahdollisesti ristiriitaiset odotukset ja näkemykset kollaboratiivisesta vuorovaikutuksesta, myös yhteistyön laajemmasta toiminta- ja kulttuurisesta ympäristöstä nousevat vuorovaikutushaasteet. Yhteistyökumppaneiden organisatoriset kytkökset voivat aiheuttaa epäselvyyttä siitä, mitä tahoja yhteiskumppanit lopulta edustavat ja mihin he ovat sitoutuneita. Toisaalta esimerkiksi talouden heilahtelut tai poliittinen päätöksenteko saattavat aiheuttaa nopeitakin muutoksia toimintaympäristössä, joilla on vaikutuksia myös pk-yritysten ja välittäjäorganisaatioiden edustajien kollaboratiiviseen vuorovaikutukseen. Muun muassa henkilöstömuu- 
tokset taustaorganisaatioissa voivat muuttaa yhteistyölle asetettuja tavoitteita ja pahimmillaan heikentää saavutettua luottamusta (Huxham \& Vangen 2000).

Tämän tutkimuksen valossa kollaboratiivinen vuorovaikutus asettaa vaatimuksia yksilöiden vuorovaikutusosaamiselle, mutta vuorovaikutusosaamisen tarkastelu pelkästään yksilötasolla ei riitä. Kollaboratiivisessa vuorovaikutuksessa keskeistä vuorovaikutusosaamista onkin syytä lähestyä ekologisen systeemin näkökulmasta (Jablin \& Sias 2001). Ekologisesta näkökulmasta eksosysteemin muutokset kuten kansainvälistyminen ja teknologinen kehitys tai makrosysteemin piirteet kuten organisaation rakenne ja johtamisfilosofia luovat vaatimuksia yksilöiden vuorovaikutusosaamiselle (mikrosysteemi). Kollaboratiivisen vuorovaikutuksen esteiden ylittäminen pk-yritysten ja välittäjäorganisaatioiden edustajien yhteistyösuhteissa edellyttää meso-, makro- ja eksosysteemien reflektointia, kuten keskustelua yhteistyökumppaneiden verkostoista, taustaorganisaatioista tai yhteistyön toiminta-, kulttuurisesta ja poliittisesta ympäristöstä sekä niiden vaikutuksista kollaboratiiviseen vuorovaikutukseen. Ekosysteemin huomioon ottaminen voi edistää esimerkiksi luottamuksen tai yhteisyyden rakentumista mikrosysteemin eli interpersonaalisen viestinnän tasolla ja auttaa hallitsemaan kollaboratiivista vuorovaikutusta ja ratkaisemaan sen ongelmia.

Vuorovaikutusosaamista kollaboratiivisessa vuorovaikutuksessa voitaisiin hahmottaa jaettuna, kollektiivisena vuorovaikutusosaamisena (collective communication competence, Thompson 2009), joka korostaa viestijöiden, vuorovaikutustavoitteiden ja viestintäkontekstien keskinäistä suhdetta. Kollektiiviseen vuorovaikutusosaamiseen tarvitaan yksilöiden kykyä havainnoida ja reflektoida muutoksia ympäristössä, kuten Thompson (2009) havaitsi etnografisessa tutkimuksessaan vuorovaikutusosaamisesta monitieteisessä tutkimusryhmässä. Hänen mukaansa keskustelu terminologia- ja näkökulmaeroista tai yhteistyöryhmän tehtävästä sekä relationaalinen viestintä, kuten huumori tai spontaani henkilökohtaisten asioiden jakaminen, edistävät kollektiivisen vuorovaikutusosaamisen kehittymistä, kun taas väittely ja vallan tavoittelu heikentävät sitä. Pk-yritysten kansainvälistymisen kontekstissa keskustelua ja reflektointia edellyttävät myös tehtävä- ja relationaalisen viestinnän jännitteinen suhde.

Yksilöiden vuorovaikutusosaamisella voi olla laajoja ja kauaskantoisia vaikutuksia paitsi kollaboratiiviseen vuorovaikutukseen interpersonaalisen viestinnän tasolla, myös organisaatioihin, toimialoihin ja laajempaan kansainväliseen liiketoimintaympäristöön. Pysyvien, henkilökohtaistenkin yhteistyösuhteiden luominen ja ylläpitäminen näyttävät tämän tutkimuksen tulosten valossa erityisen merkityksellisiltä suomalaisten pk-yritysten kansainvälistymisessä Kiinaan. Onkin ongelmallista, mikäli yhteistyökumppanit eivät saa taustayhteisöjensä tukea, eivät sitoudu yhteistyösuhteeseen tai heillä ei ole vuorovaikutusosaamista kollaboratiivisessa vuorovaikutuksessa eli niitä tietoja, taitoja ja motivaatiota, joita tarvitaan tehokkaaseen ja tarkoituksenmukaiseen vuorovaikutukseen kan- 
sainvälisessä liiketoimintayhteistyössä. Pk-yrityksen kansainvälistyminen tai vaikkapa alueellinen kehittämishanke voi epäonnistua yhden yhteistyösuhteen karikoihin. Yhteistyösuhteiden ja kollaboratiivisen vuorovaikutuksen tulisikin saada merkittävästi enemmän huomiota pk-yritysten kansainvälistymisessä.

\section{Kirjallisuus}

Agndal, H. \& Chetty, S. 2007. The impact of relationships on changes in internationalization strategies of SMEs. European Journal of Marketing 41 (11/12), 1449-1474.

Ai, J. 2006. Guanxi networks in China: its importance and future trends. China \& World Economy 14 (5), 105-118.

Arnett, R. C., Harden Fritz, J. M. \& Bell, L. M. 2009. Communication ethic literacy: dialogue and difference. Los Angeles: Sage.

Baxter, L. A. \& Montgomery, B. M. 1996. Relating: dialogues \& dialectics. New York: The Guilford Press.

Bridge, K. \& Baxter, L. A. 1992. Blended relationships: friends as work associates. Western Journal of Communication 56, 200-225.

Charles, M. 2009. The ascent of international business communication: are we on board? Teoksessa L. Louhiala-Salminen \& A. Kankaanranta (toim.) The ascent of international business communication. Helsinki: Helsinki School of Economics, 9-24.

Ellis, P. 2008. Social ties and foreign market entry. Journal of International Business Studies 31 (3), 443-469.

Forsman, M., Hinttu, S. \& Kock, S. 2002. Internationalization from a SME perspective. Esitelmä. 18th IMP Conference 9.-11.9.2002, Dijon.

Hardy, C., Lawrence, T. B. \& Grant, T. 2005. Discourse and collaboration: the role of conversations and collective identity. Academy of Management Review 30 (1), 58-77.

Heath, R. G. 2007. Rethinking community collaboration through a dialogic lens: creativity, democracy, and diversity in community organizing. Management Communication Quarterly 21, 145-171.

Heath, R.G. \& Frey, L. 2004. Ideal collaboration: a conceptual framework of community collaboration. Teoksessa P. Kalbfleisch (toim.) Communication yearbook 28. Mahwah: Lawrence Erlbaum, 189-132.

Huxham, C. \& Vangen, S. 2000. Ambiguity, complexity and dynamics in the membership of collaboration. Human Relations 52, 771-806.

Häkkinen, P. \& Arvaja, M. 1999. Kollaboratiivinen oppiminen teknologiaympäristössä. Teoksessa A. Eteläpelto \& P. Tynjälä (toim.) Oppiminen ja asiantuntijuus. Porvoo: WSOY, 206-221.

Isbell, M. 2010. Communicating social identities: exploring boundary spanners in interorganizational contexts. Esitelmä. Annual convention of the National Communication Association 14.-17.11.2010, San Francisco. 
Jablin, F. M. \& Sias, P. M. 2001. Communication competence. Teoksessa F. M. Jablin \& L. L. Putnam (toim.) The new handbook of organizational communication: advances in theory, research, and methods. Thousand Oaks: Sage, 819-864.

Johannesen, R. L. 2002. Ethics in human interaction. Long Grove: Waveland Press.

Keyton, J., Ford, D. J. \& Smith, F. I. 2008. A mesolevel communicative model of collaboration. Communication Theory 18, 376-406.

Keyton, J. \& Stallworth, V. 2003. On the verge of collaboration: identifying group structure and process. Teoksessa L. R. Frey (toim.) Group communication in context: studies of bona fide groups. Mahwah: Lawrence Erlbaum, 235-260.

Knapp, M. L., Daly, J. A., Fudge Albada, K. \& Miller, G. R. 2002. Background and current trends in the study of interpersonal communication. Teoksessa M. L. Knapp \& J. L. Daly (toim.) Handbook of interpersonal communication. Thousand Oaks: Sage, 3-20.

Kontinen, T. 2011. Internationalization pathways of family SMEs. Jyväskylän yliopisto. Jyväskylä Studies in Business and Economics 100.

Koschmann, M. 2010. Collaborative conversations: economic sectors as discursive resources in inter-organizational collaboration. Esitelmä. Annual convention of the National Communication Association 14.-17.11.2010, San Francisco.

Koskenlinna, M., Smedlund, A., Ståhle, P., Köppä, L., Niinikoski, M-L., Valovirta, V., Halme, K., Saapunki, J. \& Leskinen, J. 2005. Välittäjäorganisaatiot: moniottelijat innovaatioita edistämässä. Helsinki: Tekes, Teknologiakatsaus 168.

Lewis, L. K. 2006. Collaborative interaction: reviews of communication scholarship and a research agenda. Teoksessa C. S. Beck (toim.) Communication Yearbook 30. Mahwah: Lawrence Erlbaum, 197-247.

Mikkola, M. \& Pirttimäki, A. 2007. Tuotekehitys Kiinassa: uhka, mahdollisuus vai yhdentekevää? Espoo: VTT Tiedotteita - Research Notes 2391.

Neuendorf, K. A. 2002. The content analysis guidebook. Thousand Oaks: Sage.

Ojala, A. 2008. Internationalization of software firms: Finnish small and medium-sized software firms in Japan. Jyväskylän yliopisto. Jyväskylä Studies in Computing 89.

Purhonen, P. 2010a. Perceptions of representatives of SMEs and intermediary organizations concerning collaborative relationships in SME internationalization. Intercultural Communication Studies XIX (2), 22-36.

Purhonen, P. 2010b. Collaborative interaction in the internationalization of small- and medium-sized enterprises. David C. Lam. Institute for EastWest Studies (LEWI) Working Paper Series 106, 1-22. 
Rouhiainen-Neunhäuserer, M. 2009. Johtajan vuorovaikutusosaaminen ja sen kehittyminen: johtamisen viestintähaasteet tietoperustaisessa organisaatiossa. Jyväskylän yliopisto. Jyväskylä Studies in Humanities 128.

Selsky, J. W. \& Parker, B. 2005. Cross-sector partnerships to address social issues: challenges to theory and practice. Journal of Management 31, 849-873.

Sias, P., Krone, K. J. \& Jablin, F. M. 2002. An ecological systems perspective on workplace relationships. Teoksessa M. L. Knapp \& J. A. Daly (toim.) Handbook of interpersonal communication. Thousand Oaks: Sage, 615642.

Sias, P. \& Perry, T. 2004. Disengaging from workplace relationships: a research note. Human Communication Research 30 (4), 589-602.

So, Y. L. \& Walker, A. 2006. Explaining Guanxi: the Chinese business network. London: Routledge.

Spitzberg, B. H. 2000. What is good communication? Journal of the Association for Communication Administration 29, 103-119.

Spitzberg, B. H. \& Cupach, W. R. 1984. Interpersonal communication competence. Beverly Hills: Sage.

Stohl, C. \& Walker, K. 2002. A bona fide perspective for the future of groups: understanding collaborating groups. Teoksessa L. R. Frey (toim.) New directions in group communication. Thousand Oaks: Sage, 237-252.

Thompson, J. L. 2009. Building collective communication competence in interdisciplinary research teams. Journal of Applied Communication Research 37 (3), 278-297.

Valkonen, T. 2003. Puheviestintätaitojen arviointi: näkökulmia lukiolaisten esiintymis- ja ryhmätaitoihin. Jyväskylä yliopisto. Jyväskylä Studies in Humanities 7.

Williams, M. 2007. Building genuine trust through interpersonal emotion management: a threat regulation model of trust and collaboration across boundaries. Academy of Management Review 32 (2), 595-621.

Williams, P. 2002. The competent boundary spanner. Public Administration 80 (1), 103-124.

Wilson, S. R \& Sabee, C. M. 2003. Explicating communicative competence as a theoretical term. Teoksessa S. R. Greene \& B. R. Burleson (toim.) Handbook of communication and social interaction skills. Mahwah: Lawrence Erlbaum, 3-50.

Zoller, H. M. 2000. "A place you haven't visited before": creating the conditions for community dialogue. Southern Communication Journal 65 (2), 191-207. 